\title{
Dedication to Malcolm Warner
}

We dedicate this Special Issue to the memory of Professor Malcom Warner, former co-editor of the Asia Pacific Business Review and Emeritus Professor at the University of Cambridge.

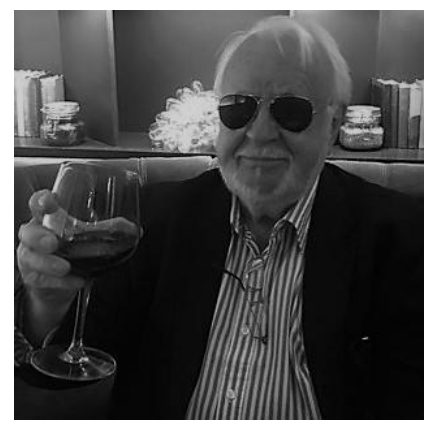

Malcolm Warner 1937-2018

Malcolm published for nearly one-half a century (1970-2018) and was an old-school renaissance man and wordsmith who loved the word 'whither'. It means, among other things, 'in what state' might we find something? Malcom frequently used it for his conceptual and 'state-of-the-field' pieces, which include, amongst many others:

- “Whither Yugoslav Self-Management” Industrial Relations Journal. 19756 (1)

- “Introduction: Whither the Iron Rice-Bowl?” in M. Warner (ed) Changing Workplace Relations in the Chinese Economy. 2000. London: Palgrave Macmillan

- “Whither International Human Resource Management?” International Journal of HRM. $2007,16(5)$

- "Whither Japan? Economy, Management and Society" Asia Pacific Business Review. 2011. $17(1)$ 
- Whither South East Asian Management? The First Decade of the New Millennium? 2011.

London: Routledge

- Whither Chinese HRM? Paradigms, models and theories. 2014. London: Routledge

- "Whither 'Confucian Management?" " Frontiers of Philosophy in China. 2016. 11 (4)

It was typical of his wry outlook to take an archaic word derived from Old English, a West

Germanic dialect of the $5^{\text {th }}$ century, to describe the extensive changes he witnessed in Asia over the course of his lifetime. We believe this Special Issue is the last of his 'whither' projects and we are proud to have worked with him on its development.

Indeed, even at the very end of his long journey he continued to work and his outlook reminded us of the prescient and pertinent poem by Dylan Thomas: 'Do Not Go Gentle Into That Good Night':

Do not go gentle into that good night, Old age should burn and rave at close of day; Rage, rage against the dying of the light.

We salute him in his Ray-Ban's raising a glass to life. We miss him and his warm, gentle bonhomie.

Dr Jane Nolan, Associate Professor, University of Nottingham, UK Professor Chris Rowley, Kellogg College, University of Oxford UK and Cass Business School, City, University of London, UK

See also Rowley (2019) "Eulogies: Obituary: Professor Malcolm Warner, Former Co-editor of Asia Pacific Business Review, Asia Pacific Business Review, 25 (1): 1-2 
